\title{
PENGARUH MEKANISME CORPORATE GOVERNANCE, UKURAN PERUSAHAAN DAN DEBT TO EQUITY RATIO TERHADAP KONSERVATISME AKUNTANSI
}

(Studi Empiris Pada Perusahaan Perbankan Yang Terdaftar di Bursa Efek Indonesia Tahun 2012-2019)

\author{
Desy Purwasih \\ Prodi Akuntansi, Fakultas Ekonomi, Universitas Pamulang \\ Email : dosen02424@unpam.ac.id
}

\begin{abstract}
This study aims to examine the effect of corporate governance mechanisms, firm size and debt to equity ratio on accounting conservatism. Accounting conservatism is measured using the Earnings / accrual measures approach. The corporate governance mechanism consists of the proportion of independent commissioners measured, managerial ownership and institutional ownership, all of which are measured using their respective percentages in the company. Company size is measured using the Natural log (total assets). Debt to Equity Ratio is calculated by comparing the value of debt to the value of capital. The population in this study were 46 companies. The sample technique used was purposive sampling, and the sample size was 23 companies. The model used in this research is panel data regression using the Eviews 8.0 application. The results of this study indicate that the proportion of independent commissioners, managerial ownership and institutional ownership has no effect on accounting conservatism, and the debt to equity ratio and firm size have a significant positive effect on accounting conservatism. The proportion of independent commissioners, managerial ownership, institutional ownership, company size and debt to equity ratio together have a significant effect on accounting conservatism.
\end{abstract}

Keyword : Corporate governance mechanisms; company size; DER; conservatism accounting

\begin{abstract}
Abstrak
Penelitian ini bertujuan untuk menguji pengaruh pengaruh mekanisme corporate governance, ukuran perusahaan dan debt to equity ratio terhadap konservatisme akuntansi. Konservatisme akuntasi diukur menggunakan pendekatan Earnings/accrual measures. Mekanisme corporate governance terdiri dari proporsi komisaris independen, kepemilikan manajerial dan kepemilikan institusional semuanya diukur menggunakan persentase masing-masing di dalam perusahaan. Ukuran perusahaan diukur dengan menggunakan log Natural (total
\end{abstract}


aset). Debt to Equity Ratio dihitung dengan membandingkan nilai hutang dengan nilai modal. Populasi dalam penelitian ini sebanyak 46 perusahaan. Teknik sampel yang digunakan adalah Purposive Sampling diperoleh jumlah sampel sebanyak 23 perusahaan. Model yang digunakan dalam penelitian ini adalah regresi data panel menggunakan aplikasi Eviews 8.0. Hasil penelitian ini menunjukkan bahwa proporsi komisaris independen, kepemilikan manajerial dan kepemilikan institusional tidak berpengaruh terhadap konservatisme akuntansi, debt to equity ratio dan ukuran perusahaan berpengaruh positif signifikan terhadap konservatisme akuntansi. Proporsi komisaris independen, kepemilikan manajerial, kepemilikan institusional, ukuran perusahaan dan debt to equity ratio secara bersama-sama berpengaruh signifikan terhadap konservatisme akuntansi.

Kata Kunci : Mekanisme corporate governance, ukuran perusahaan, DER, Konservtisme Akuntansi

\section{PENDAHULUAN}

Bank dihadapkan dengan berbagai risiko, baik risiko kredit, risiko pasar, risiko operasional maupun risiko reputasi dalam menjalankan kegiatan usahanya. Krisis perbankan di Indonesia yang terjadi pada akhir tahun 1997 bukan semata-mata diakibatkan oleh krisis ekonomi, tetapi juga diakibatkan oleh belum terlaksananya good corporate governance dan etika yang melandasinya (Zarkasyi:2008). Oleh karena itu, usaha mengembalikan kepercayaan kepada dunia perbankan Indonesia melalui restrukturisasi dan rekapitulasi hanya dapat mempunyai dampak jangka panjang dan mendasar apabila disertai tiga tindakan penting lain yaitu : (1) Ketaatan terhadap prinsip kehati-hatian (konservatisme); (2) Pelaksanaan good corporate governance; (3) Pengawasan yang efektif dari Otoritas Pengawas Bank (Zarkasyi:2008).

Salah satu usaha yang dilakukan oleh perusahaan perbankan untuk mencapai tujuannya adalah menerapkan prinsip konservatisme.. Konservatisme merupakan prinsip dalam pelaporan keuangan yang dirancang secara hati-hati untuk mengakui dan mengukur aktiva dan laba melalui kegiatan ekonomi dan bisnis dalam suatu perusahaan (Wibowo, 2002 dalam Millah et al, 2020). Sterling dalam Belkaoui (2004), menyebut konservatisme sebagai "prinsip penilaian akuntansi yang paling kuno dan mungkin paling bertahan." Konservatisme dipandang lebih sebagai pedoman untuk diikuti dalam situasi luar biasa, dan bukan sebagai aturan umum untuk diterapkan secara kaku dalam semua situasi. Konsep konservatisme terhadap prinsip akuntansi yaitu mengakui biaya atau rugi yang terjadi secepat mungkin, tetapi tidak segera mengakui pendapatan atau laba dimasa depan. Implikasi tersebut berakibat pada pelaporan laba dan aset yang rendah sedangkan hutang yang lebih tinggi (Calvin Oktomegah, 2012 dalam Millah et al, 2020).

Konservatisme masih digunakan dalam beberapa situasi yang memerlukan penilaian akuntan. Banyak pro kontra yang terjadi ketika kita membicarakan konservatisme. Konservatisme dianggap menjadi suatu prinsip yang justru membuat informasi suatu laporan keuangan menjadi bias karena

* Corresponding author's e-mail: dosen02424@unpam.ac.id

http://openjournal.unpam.ac.id/index.php/JABI 
konservatisme pada dasarnya mengakui rugi lebih cepat dan laba lebih lambat. Hal ini akan membuat suatu laporan keuangan tidak mencerminkan kondisi perusahaan yang sebenarnya. Di sisi lain, konservatisme dianggap perlu untuk digunakan untuk mencegah kecenderungan manajemen dalam menilai aset perusahaan secara overstated agar kinerjanya dinilai baik dan harga saham perusahaan dapat meningkat. Lafond dan Watts, 2003 dalam Millah et al (2020) juga menjelaskan bahwa asimetri informasi pelaporan keuangan yang konservatif dapat mencegah asimetri informasi dengan membatasi manajemen memanipulasi pelaporan keuangan.

Beberapa kasus manipulasi akuntansi yang terjadi sekarang ini berhubungan dengan adanya indikasi manipulasi laporan keuangan (Gideon, 2005). Contoh kecurangan tersebut adalah manipulasi laporan keuangan yang dilakukan oleh CEO Toshiba Corp, Mengutip Reuters, Rabu (22/7/2015), Tim penyelidik independen menemukan bahwa CEO mengetahui bahwa perusahaan memanipulasi laporan keuntungannya dengan nilai mencapai US\$1,2 miliar selama beberapa tahun terakhir. CEO ditekan divisi bisnis untuk memenuhi target yang sulit, dan mereka melebih-lebihkan laba dan menunda laporan kerugian, di tengah budaya tidak akan melawan keinginan atasan, menurut penyelidikan. (liputan 6, 22 juli 2015). Dari kasus tersebut, perusahaan tidak jarang melibatkan pihak internal perusahaan yaitu CEO, komisaris, komite audit, internal auditor dan jajaran manajemen puncak lainnya. Akibat hal tersebut, menimbulkan berbagai pemikiran di benak masyarakat bahwa penerapan good corporate governance di perusahaan tersebut dirasa masih lemah atau belum diterapkan dengan baik.

Wardhani (2008) menyatakan bahwa konservatisme akuntansi dalam perusahaan diterapkan dalam tingkatan yang berbeda-beda. Salah satu faktor yang sangat menentukan tingkatan konservatisme dalam pelaporan keuangan suatu perusahaan adalah komitmen manajemen dan pihak internal perusahaan dalam memberikan informasi yang transparan, akurat dan tidak menyesatkan bagi investornya. Hal tersebut merupakan suatu bagian dari implementasi corporate governance. Implementasi dari corporate governance dilakukan oleh seluruh pihak dalam perusahaan, Konsep konservatisme merupakan alat yang sangat berguna bagi komisaris independen dalam menjalankan fungsi mereka sebagai pengambil keputusan dan pihak yang memonitor manajemen. Pihak institusional maupun manajerial (komisaris dan direksi) yang menanamkan saham juga turut berpartisipasi dalam mengawasi jalannya perusahaan, sehingga mereka akan mensyaratkan laporan keuangan yang menghasilkan informasi yang berkualitas, hal tersebut akan mendorong perusahaan untuk menggunakan prinsip konservatisme.

Ukuran perusahaan akan mempengaruhi tingkat biaya politis yang dihadapi perusahaan sehingga akan mempengaruhi penggunaan prinsip akuntansi yang konservatis (Watts dan Zimmerman, 1978 dalam Wardhani, 2008). Oktomegah (2012) juga mengungkapkan bahwa perusahaan yang memiliki ukuran besar akan menghadapi biaya politis yang lebih tinggi, sehingga akan mendorong mereka untuk lebih menggunakan prinsip akuntansi yang konservatisme untuk mengurangi biaya politis tersebut.

* Corresponding author's e-mail: dosen02424@unpam.ac.id

http://openjournal.unpam.ac.id/index.php/JABI 
Debt to equity ratio (DER) merupakan proksi dari leverage, yaitu perbandingan total hutang terhadap total modal yang dimiliki perusahaan. Hutang yang didapat oleh perusahaan pada umumnya diberikan oleh pihak eksternal atau kreditor sehingga perusahaan harus berhati-hati dan memikirkan alternatif-alternatif yang perlu dipertimbangkan dalam pengambilan keputusan terkait dengan kebijakan hutang. Ketika perusahaan memilih debt to equity ratio yang tinggi, perusahaan harus mempertimbangkan kembali keputusannya, karena dengan adanya hutang yang tinggi berarti akan ada campur tangan dari pihak eksternal atau kreditor, sehingga dapat dipertimbangkan penggunaan prisnsip konservatisme atau tidak.

Penelitian tentang konservatisme akuntansi telah banyak dilakukan namun hasilnya masih belum konsisten. Penelitian sebelumnya yang dilakukan oleh Veres (2013) dan Mulya (2014), yang menyatakan bahwa proporsi dewan komisaris tidak mempunyai pengaruh signifikan terhadap konservatisme akuntansi. Penelitian yang dilakukan oleh Veres (2013) juga menyatakan bahwa kepemilikan manajerial tidak mempunyai pengaruh terhadap konservatisme akuntansi.

Penelitian yang dilakukan oleh Veres (2013) dan Mulya (2014) menunjukan bahwa kepemilikan institusional tidak mempunyai pengaruh signifikan terhadap konservatisme akuntansi berbeda dengan Yustina (2013) yang menyatakan bahwa kepemilikan institusional memiliki pengaruh signifikan terhadap konservatisme akuntansi. Penelitian yang dilakukan oleh Mulya (2014), menguji ukuran perusahaan. Hasilnya variabel ukuran perusahaan mempunyai pengaruh signifikan terhadap konservatisme akuntansi, berbeda dengan Zulaikha (2012) yang menyatakan bahwa ukuran perusahaan tidak berpengaruh signifikan terhadap konservatisme akuntansi. Fina, et.al (2016) menguji leverage dengan proksi debt equity ratio hasil penelitian menunjukkan variabel leverage dengan proksi debt to equity ratio berpengaruh signifikan terhadap konservatisme akuntansi.

Melihat adanya hasil yang tidak konsisten di antara beberapa penelitian tersebut, menjadikan hal menarik untuk diteliti kembali. Penelitian ini mencoba menguji kembali pengaruh mekanisme Corporate Governance yang terdiri dari proporsi dewan komisaris, kepemilikan manajerial dan kepemilikan institusional serta ukuran perusahaan dan debt to equity ratio terhadap konservatisme akuntansi. Oleh karena itu, penulis tertarik untuk mengambil judul penelitian "Pengaruh Mekanisme Corporate Governance, Ukuran Perusahaan dan Debt to Equity Ratio terhadap Konservatisme Akuntansi (studi empiris pada perusahaan perbankan yang terdaftar di BEI periode 20122019)".

\section{KERANGKA TEORITIS DAN PENGEMBANGAN HIPOTESIS}

Menurut Jensen dan Meckling (1976) dalam Agustin, et,al (2019), teori agensi adalah sebuah kontrak antara principal (pemilik/pemegang saham) dan agent (manajer/pengelola) yang mana baik pemilik dan pengelola sama-sama

* Corresponding author's e-mail: dosen02424@unpam.ac.id

http://openjournal.unpam.ac.id/index.php/JABI 
melakukan pemaksimuman kesejahteraan. Teori agensi merupakan teori yang muncul karena adanya konflik kepentingan antara prinsipal dan agen, yang dapat mempengaruhi kualitas laba yang dilaporkan perusahaan.

Perbedaan tujuan yang dimiliki oleh prinsipal dan agen dapat mengarah kepada ketidakseimbangan informasi atau yang disebut dengan asimetri informasi. Definisi asymmetry information oleh Pyndick dalam Haniati dan Fitriany (2010) adalah "one side of negotiation process has better information than the other". Dari definisi tersebut dapat disimpulkan bahwa asimetri informasi akan terjadi apabila ada dua belah pihak yang memiliki informasi berbeda karena salah satu pihak memiliki informasi yang lebih jelas dan terperinci dibandingkan pihak yang lainnya. Sehingga, asimetri informasi bisa dijelaskan sebagai situasi yang terbentuk karena prinsipal (pemegang saham) tidak memiliki informasi yang cukup mengenai kinerja agen (manajer) sehingga pemegang saham mengalami keadaan tidak dapat menentukan kontribusi usaha-usaha manajer yang sesungguhnya terhadap hasil-hasil perusahaan dalam meningkatkan kesejahteraan pemegang saham. Asimetri informasi dan konflik kepentingan yang terjadi antara prinsipal dan agen akan mendorong agen untuk menyajikan informasi yang tidak sebenarnya kepada prinsipal, terutama jika informasi yang berkaitan dengan kinerja agen dengan cara memikirkan bagaimana angka akuntansi tersebut digunakan sebagai sarana untuk memaksimalkan kepentingannya.

Menurut Scott (2009:8) dalam Oktomegah (2012), terdapat 2 macam asimetri informasi, yaitu: (1) Adverse selection yaitu bahwa para manajer serta orang-orang dalam lainnya memiliki lebih banyak pengetahuan tentang keadaan dan prospek perusahaan dibandingkan dengan investor selaku pihak luar. Informasi mengenai fakta yang mungkin dapat mepengaruhi keputusan yang akan diambil oleh pemegang saham tidak disampaikan oleh manajer kepada pemegang saham. (2) Moral hazard yaitu bahwa kegiatan yang dilakukan oleh manajer tidak seluruhnya diketahui oleh pemegang saham maupun kreditur. Sehingga manajer dapat melakukan tindakan yang melanggar kontrak dan secara etika atau norma tidak layak untuk dilakukan di luar sepengetahuan pemegang saham

Pihak manajemen yang mempunyai kepentingan tertentu akan cenderung menyusun laporan laba yang sesuai dengan tujuannya dan bukan demi untuk kepentingan prinsipal. Sebagai contohnya, manajer akan memilih metode konservatisme tidak terlepas dari keinginan untuk mengoptimalkan kinerjanya dalam perusahaan yang dapat menyebabkan adanya masalah keagenan antara manajer (agen) dengan pemilik saham (prinsipal).

Definisi resmi dari konservatisme terdapat di dalam Glosarium pernyataan konsep No.2 FASB (Financial Accounting Standard Board), "Konservatisme adalah reaksi yang hati-hati (prudent reaction) dalam menghadapi ketidakpastian dan risiko yang inheren dalam lingkungan bisnis sudah cukup dipertimbangkan" disampaikan oleh (Givoly \& Hayn, 2002). Watts (2003) mendefinisikan konservatisme sebagai tindakan manajemen dengan lebih mengantisipasi tidak ada profit dan lebih cepat mengakui kerugian. 
Menurut Watss (2003), (dalam Sari 2009), terdapat tiga ukuran yang dapat digunakan sebagai alat ukur konservatisme yaitu, 1) Earnings atau Stock Return Realtion Measures, 2) Earnings atau Accrual Measures, dan 3) Net Asset Measures. Perhitungan konservatisme dalam penelitian ini menggunakan earning atau accrual measures. Ukuran konservatisme dengan menggunakan akrual, yaitu dengan menghitung selisih antara net income (laba bersih) dan cash flow. melihat adanya kecenderungan dari akun akrual selama beberapa tahun. Apabila terjadi akrual negatif (net income lebih kecil daripada cash flow operasional) yang konsisten selama beberapa tahun, maka hal tersebut merupakan indikasi diterapkannya konservatisme.

Wardhani (2008) menyatakan bahwa corporate governance dapat diartikan sebagai susunan aturan yang menentukan hubungan antara pemegang saham, manajer, kreditor, pemerintah, karyawan dan stakeholder internal maupun eksternal yang lain sesuai dengan hak dan tanggungjawabnya. Corporate governance biasanya mengacu pada sekumpulan mekanisme yang mempengaruhi keputusan yang akan diambil oleh manajemen ketika ada pemisahan antara kepemilikan dan pengendalian beberapa dari pengendalian ini terletak pada fungsi dari dewan direksi, pemegang saham institusional, dan pengendalian dari mekanisme pasar. Mekanisme corporate governance akan digunakan sebagai faktor yang diduga dapat mendorong konservatisme akuntansi, dimana mekanisme corporate governance disini terdiri dari proporsi dewan komisaris independen, kepemilikan manajerial dan kepemilikan institusional.

Komisaris independen merupakan anggota dewan komisaris yang berasal dari luar perusahaan (tidak memiliki hubungan afiliasi dengan perusahaan) yang dipilih secara transparan dan independen, memiliki integritas dan bebas dari pengaruh yang berhubungan dengan kepentingan pribadi atau pihak lain, serta dapat bertindak secara objektif dan independen dengan berpedoman pada prinsip-prinsip corporate governance. Menurut Akhtaruddin, et al, (2009) dalam Agustin, et,al (2019), menyatakan bahwa jika nilai proporsi komisaris independen tinggi berkaitan dengan transparansi perusahaan dan dapat dinilai sejauh mana pengungkapan informasi yang telah dilakukan perusahaan. Komisaris independen yang dimiliki sekurang-kurangnya 30\% (tiga puluh persen) dari jumlah seluruh anggota komisaris, berarti telah memenuhi pedoman corporate governance guna menjaga independensi, pengambilan keputusan yang efektif, tepat, dan cepat (Wardhani, 2008).

Christiawan dan Tarigan (2007), dalam Nugroho (2012) menyatakan bahwa kepemilikan manajerial merupakan kepemilikan saham perusahaan oleh manajer atau dengan kata lain manajer tersebut sekaligus sebagai pemegang saham. (Gunarto,Kelvin dan Riswandari, Erni, 2019), juga menjelaskan bahwa struktur kepemilikan menggambarkan komposisi kepemilikan saham dari suatu perusahaan, salah satu dari struktur kepemilikan adalah kepemilikan manajerial. Kepemilikan manajerial merupakan pemegang saham dari pihak manajemen (direktur dan komisaris), yang secara aktif ikut dalam pengambilan keputusan perusahaan. Seperti yang dijelaskan oleh teori agensi terdapat hubungan keagenan antara manajer dan prinsipal, proporsi kepemilikan saham

* Corresponding author's e-mail: dosen02424@unpam.ac.id

http://openjournal.unpam.ac.id/index.php/JABI 
oleh pihak manajemen perusahaan dapat mempengaruhi tingkat konservatisme lebih tinggi yang diterapkan oleh perusahaan dalam menyusun laporan keuangannya.

Kepemilikan institusional merupakan persentase jumlah saham yang dimiliki oleh pihak institusional dari seluruh jumlah saham perusahaan yang beredar. Pihak institusional diantaranya perusahaan asuransi, bank, perusahaanperusahaan investasi dan kepemilikan oleh institusi-institusi lain. Menurut Ahmed (2007), "Dengan adanya kepemilikan institusional yang tinggi maka pemegang saham institusional ini dapat menggantikan atau memperkuat fungsi monitoring dari dewan dalam perusahaan".

Ukuran perusahaan merupakan suatu skala dimana diklasifikasikannya perusahaan menurut besar kecilnya (Mutia, Et, al 2011). Berdasarkan ukurannya perusahaan dibagi menjadi perusahaan kecil dan besar, dimana perusahaan yang besar memiliki sistem manajemen yang lebih kompleks dan memiliki laba yang lebih tinggi pula.

Menurut Kasmir (2009), DER merupakan rasio yang digunakan untuk mengetahui seberapa besar kemampuan perusahaan dalam membayarkan seluruh kewajibannya (baik kewajiban jangka pendek maupun kewajiban jangka panjang). Sehingga DER menunjukan seberapa besar aset perusahaan dibiayai oleh hutang dan merupakan indikasi tingkat keamanan dari para pemberi pinjaman. Semakin tinggi tingkat $D E R$, semakin besar kemungkinan perusahaan akan melanggar perjanjian kredit.

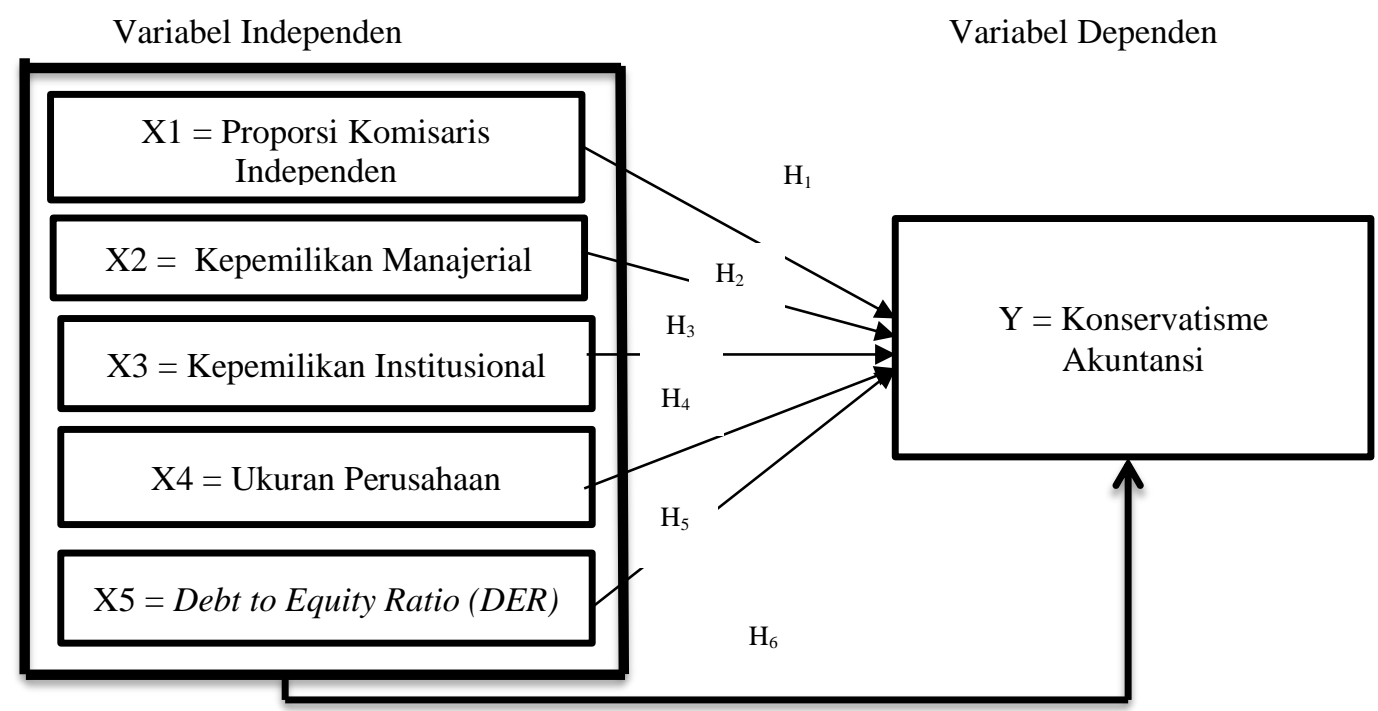

Sumber : data yang diolah penulis, 2020

Gambar 1. Kerangka Pemikiran

Hipotesis yang diuji dalam penelitian ini adalah :

$\mathrm{H}_{1}$ : Proporsi komisaris independen berpengaruh negatif signifikan terhadap konservatisme akuntansi 
$\mathrm{H}_{2}$ : Kepemilikan manajerial berpengaruh negatif signifikan terhadap konservatisme akuntansi

$\mathrm{H}_{3}$ : Kepemilikan institusional berpengaruh positif signifikan terhadap konservatisme akuntansi

$\mathrm{H}_{4}$ : Ukuran perusahaan berpengaruh positif signifikan terhadap konservatisme akuntansi

$\mathrm{H}_{5}$ : DER berpengaruh positif signifikan terhadap konservatisme akuntansi

$\mathrm{H}_{6}$ : Proporsi komisaris independen, kepemikan manajerial, kepemilikan institusional, ukuran perusahaan dan DER berpengaruh signifikan secara bersama-sama terhadap konservatisme akuntansi.

\section{METODE PENELITIAN}

Penelitian ini adalah penelitian dengan pendekatan assosiatif kausalitas dengan menggunakan data kuantitatif yang dapat diolah atau dianalisis menggunakan teknik perhitungan statistika yang bertujuan untuk menganalisis bagaimana suatu variabel mempengaruhi variabel lain. Populasi dalam penelitian ini adalah perusahaan perbankan yang terdaftar di Bursa Efek Indonesia periode 2012-2019. Penentuan sampel dalam penelitian ini menggunakan teknik nonprobability sampling lebih khususnya teknik purposive sampling, yaitu teknik penentuan sampel dengan pertimbangan khusus atau kriteria tertentu sehingga layak dijadikan sampel penelitian.

Proses Pemilihan sampel disajikan dalam tabel 1, sebagai berikut :

Tabel 1. Prosedur Pemilihan Sampel

\begin{tabular}{|l|c|}
\hline \multicolumn{1}{|c|}{ Kriteria Sampel Penelitian } & Jumlah \\
\hline $\begin{array}{l}\text { Perusahaan pada sektor perbankan yang terdaftar di BEI, periode } \\
2012-2019\end{array}$ & 46 perusahaan \\
\hline $\begin{array}{l}\text { Perusahaan perbankan yang menerbitkan laporan keuangan } \\
\text { menggunakan mata uang rupiah }\end{array}$ & 46 perusahaan \\
\hline $\begin{array}{l}\text { Perusahaan perbankan yang tidak delisting selama tahun 2012-2016 } \\
\text { Perusahaan perbankan yang mempublikasikan laporan keuangan } \\
\text { secara berturut-turut dari tahun 2012-2016. }\end{array}$ & 36 perusahaan \\
\hline $\begin{array}{l}\text { Perusahaan perbankan yang telah terdaftar di BEI sebelum tahun } \\
\text { penelitian. }\end{array}$ & 32 perusahaan \\
\hline $\begin{array}{l}\text { Perusahaan perbankan yang secara konsisten mencantumkan data } \\
\text { yang dibutuhkan penulis, seperti data dewan komisaris, kepemilikan } \\
\text { manajerial dan kepemilikan institusional }\end{array}$ & 23 perusahaan \\
\hline Jumlah perusahaan yang memenuhi kriteria sampel & 23 perusahaan \\
\hline \begin{tabular}{l} 
Jumlah Observasi (Sampel Akhir x Tahun Pengamatan) \\
\hline
\end{tabular}
\end{tabular}

Sumber : Data yang diolah penulis, 2020 
Tabel 2. Operasionalisasi Variabel

\begin{tabular}{|c|c|c|}
\hline Variabel & Skala & Rumus \\
\hline Konservatisme (Dependen) & Rasio & $\begin{array}{r}\mathbf{C}_{\mathbf{i t}}=\mathbf{N}_{\mathbf{i t}}-\mathbf{C F}_{\text {it }} \\
\text { sumber : Mulya (2014) }\end{array}$ \\
\hline $\begin{array}{l}\text { Proporsi Komisaris } \\
\text { Independen (Independen) }\end{array}$ & Rasio & $\begin{array}{l}\text { Jumlah komisaris independen } \\
\text { Total dewan komisaris } \\
\text { sumber : Mulya (2014) }\end{array}$ \\
\hline $\begin{array}{l}\text { Kepemilikan Manajerial } \\
\text { (Independen) }\end{array}$ & Rasio & $\begin{array}{l}\text { Jumlah saham yang dimiliki manajer } \\
\text { Total saham yang beredar } \\
\text { sumber: Mulya (2014) }\end{array}$ \\
\hline $\begin{array}{l}\text { Kepemilikan Institusional } \\
\text { (Independen) }\end{array}$ & Rasio & $\begin{array}{l}\text { Jumlah saham yang dimiliki institusi } \\
\text { Total saham yang beredar } \\
\text { sumber : Mulya (2014) }\end{array}$ \\
\hline $\begin{array}{l}\text { Ukuran Perusahaan } \\
\text { (Independen) }\end{array}$ & Rasio & $\begin{array}{l}\text { Log natural (Total aset) } \\
\text { sumber : Mulya (2014) }\end{array}$ \\
\hline$D E R$ (Independen) & Rasio & $\begin{array}{r}\text { Total Hutang } \\
\text { Total Modal } \\
\text { Sumber : Fina, et,al (2016) }\end{array}$ \\
\hline
\end{tabular}

Sumber : Data yang diolah penulis, 2020

Teknik Analisis Data

Dalam penelitian ini, teknik yang digunakan adalah teknik analisis berganda. Model ini dipakai karena variabel dependen dalam penelitian ini dalam bentuk skala rasio, demikian pula pada keempat variabel independen yang merupakan skala rasio. Model ini dianalisis dengan menggunakan software Eviews8 dan bertujuan untuk membuktikan hubungan dari variabel independen terhadap variabel dependen. Bentuk umum persamaan regresi berganda yang digunakan dalam penelitian ini adalah sebagai berikut :

$$
\mathrm{KONS}=\alpha+\beta_{1} \mathrm{KOMIND}+\beta_{2} \mathrm{KEPMAN}+\beta_{3} \mathrm{KEPINST}+\beta_{4} \mathrm{UKR}+\beta_{5} D E R_{+} \mathrm{e}
$$

Di mana:

$$
\begin{array}{ll}
\text { Y } & =\text { konservatisme } \\
\alpha & =\text { konstanta } \\
\boldsymbol{\beta} & =\text { koefesien } \\
\text { KOMIND } & =\text { proporsi komisaris independen } \\
\text { KEPMAN } & =\text { kepemilikan manajerial } \\
\text { KEPINST } & =\text { kepemilikan institusional } \\
\text { UKR } & =\text { ukuran perusahaan }
\end{array}
$$




$$
\begin{array}{ll}
D E R & =\text { debt to equity ratio } \\
\mathbf{e} & =\text { error }
\end{array}
$$

\section{HASIL PENELITIAN DAN PEMBAHASAN}

Analisis Deskriptif

Pengujian statistik deskriptif ini dilakukan untuk memahami variabel-variabel yang digunakan dalam penelitian. Berikut tabel deskriptif dalam penelitian ini:

Tabel 3. Hasil Uji Statistik Deskriptif

$\begin{array}{lcccccc} & \text { KONS } & \text { KOMIND } & \text { KEPMAN } & \text { KEPINST } & \text { UKR } & \text { DER } \\ \text { Mean } & -0.010066 & 0.527868 & 0.011937 & 0.792924 & 17.84659 & 6.619637 \\ \text { Median } & -0.005756 & 0.500000 & 0.000000 & 0.854537 & 17.41958 & 6.062512 \\ \text { Maximum } & 0.210055 & 1.000000 & 0.265346 & 0.999999 & 24.02162 & 18.20747 \\ \text { Minimum } & -0.858181 & 0.000000 & 0.000000 & 0.442170 & 14.74797 & 0.778937 \\ \text { Std. Dev. } & 0.086326 & 0.163981 & 0.043952 & 0.165668 & 1.820223 & 2.638752 \\ \text { Skewness } & -5.139455 & -1.225854 & 4.328942 & -0.585581 & 0.900542 & 0.883598 \\ \text { Kurtosis } & 52.22900 & 6.542775 & 21.99063 & 1.877353 & 4.059392 & 4.527914 \\ & & & & & & \\ \text { Jarque-Bera } & 19390.15 & 142.3096 & 3339.623 & 20.17833 & 33.47431 & 41.84085 \\ \text { Probability } & 0.000000 & 0.000000 & 0.000000 & 0.000042 & 0.000000 & 0.000000 \\ & & & & & & \\ \text { Sum } & -1.852087 & 97.12778 & 2.196419 & 145.8980 & 3283.772 & 1218.013 \\ \text { Sum Sq. } & & & & & & \\ \text { Dev. } & 1.363737 & 4.920855 & 0.353522 & 5.022595 & 606.3177 & 1274.232 \\ & & & & & & \\ \text { Observations } & 184 & 184 & 184 & 184 & 184 & 184\end{array}$

Sumber: Data diolah penulis, 2020

\section{Pemilihan Model Estimasi}

Uji F Restricted (Uji Chow)

Tabel 4. Hasil Uji Chow

Redundant Fixed Effects Tests

Equation: Untitled

Test cross-section fixed effects

\begin{tabular}{lrrr}
\hline \hline Effects Test & Statistic & d.f. & Prob. \\
\hline \hline Cross-section F & & & \\
Cross-section Chi-square & 0.370822 & $(22,155)$ & 0.9957 \\
\hline \hline
\end{tabular}

Sumber : Data Diolah Penulis, 2020

* Corresponding author's e-mail: dosen02424@unpam.ac.id

http://openjournal.unpam.ac.id/index.php/JABI 
Berdasarkan uji chow pada tabel 4, nilai probabilitas cross-section chisquare menunjukkan nilai sebesar 0,9911 yang berarti lebih besar dari $\alpha$ $(0,05)$ sehingga $\mathrm{H}_{0}$ diterima dan sehingga model yang terpilih dari hasil uji chow adalah model common effect.

\section{Uji Langrange Multiplier}

\section{Tabel 6. Hasil Uji Langrange Multiplier}

Lagrange Multiplier Tests for Random Effects

Null hypotheses: No effects

Alternative hypotheses: Two-sided (Breusch-Pagan) and one-sided

(all others) alternatives

\begin{tabular}{|c|c|c|c|}
\hline & \multicolumn{3}{|c|}{ Test Hypothesis } \\
\hline & Cross-section & Time & Both \\
\hline \multirow[t]{2}{*}{ Breusch-Pagan } & 6.163702 & 0.579399 & 6.743101 \\
\hline & $(0.0130)$ & $(0.4465)$ & $(0.0094)$ \\
\hline \multirow[t]{2}{*}{ Honda } & -2.482680 & -0.761182 & -2.293757 \\
\hline & $(0.9935)$ & $(0.7767)$ & $(0.9891)$ \\
\hline \multirow[t]{2}{*}{ King-Wu } & -2.482680 & -0.761182 & -1.882731 \\
\hline & $(0.9935)$ & $(0.7767)$ & $(0.9701)$ \\
\hline \multirow[t]{2}{*}{ Standardized Honda } & -2.037132 & -0.539511 & -6.349571 \\
\hline & $(0.9792)$ & $(0.7052)$ & $(1.0000)$ \\
\hline \multirow[t]{2}{*}{ Standardized King-Wu } & -2.037132 & -0.539511 & -5.425452 \\
\hline & $(0.9792)$ & $(0.7052)$ & $(1.0000)$ \\
\hline \multirow[t]{2}{*}{ Gourieroux, et al.* } & -- & -- & 0.000000 \\
\hline & & & $(1.0000)$ \\
\hline
\end{tabular}

Sumber : Data Diolah Penulis, 2020

Berdasarkan uji langrange multiplier pada tabel 6, nilai Both-Breusch pagan menunjukkan nilai sebesar 0,0094 yang berarti lebih kecil dari $\alpha(0,05)$, sehingga $\mathrm{H}_{0}$ tidak dapat diterima dan model yang terpilih adalah random effect model. 
Jurnal Akuntansi Berkelanjutan Indonesia - Vol. 3, No. 3, Sep 2020 - Purwasih

Kesimpulan pemilihan model estimasi

Tabel 7.Kesimpulan Model

\begin{tabular}{|l|l|l|}
\hline \multicolumn{1}{|c|}{ Jenis Uji } & \multicolumn{1}{|c|}{ Perbandingan Model } & Model Terpilih \\
\hline Uji Chow & CEM vs FEM & CEM \\
\hline Uji Lagrange Multiplier & CEM vs REM & REM \\
\hline
\end{tabular}

Sumber : Data Yang Diolah Penulis, 2020

Kesimpulan dari uji pemilihan model seperti yang dijabarkan pada tabel 7, model analisis regresi yang paling cocok untuk penelitian ini adalah Random Effect Model.

Analisis Regresi Berganda

Tabel 8. Hasil Analisis Regresi Berganda Model Random Effect

Dependent Variable: KONS2

Method: Panel EGLS (Cross-section random effects)

Date: 08/22/20 Time: 08:11

Sample: 20122019

Periods included: 8

Cross-sections included: 23

Total panel (unbalanced) observations: 183

Swamy and Arora estimator of component variances

\begin{tabular}{|c|c|c|c|c|}
\hline Variable & Coefficient & Std. Error & t-Statistic & Prob. \\
\hline & -7.247993 & 1.473026 & -4.920478 & 0.0000 \\
\hline KOMIND & -0.377902 & 0.932552 & -0.405234 & 0.6882 \\
\hline KEPMAN & 0.092067 & 0.066215 & 1.390423 & 0.1746 \\
\hline KEPINST & -0.474711 & 1.153784 & -0.411438 & 0.6837 \\
\hline UKR & 0.267180 & 0.090754 & 2.943999 & 0.0062 \\
\hline DER & 1.428793 & 0.457733 & 3.121459 & 0.0040 \\
\hline \multicolumn{5}{|c|}{ Effects Specification } \\
\hline & & & S.D. & Rho \\
\hline Cross-section random & & & 0.166960 & 0.0463 \\
\hline Idiosyncratic random & & & 0.757445 & 0.9537 \\
\hline \multicolumn{5}{|c|}{ Weighted Statistics } \\
\hline R-squared & 0.367863 & \multirow{5}{*}{\multicolumn{2}{|c|}{$\begin{array}{l}\text { Mean dependent var } \\
\text { S.D. dependent var } \\
\text { Sum squared resid } \\
\text { Durbin-Watson stat }\end{array}$}} & -3.466938 \\
\hline Adjusted R-squared & 0.262507 & & & 0.861611 \\
\hline S.E. of regression & 0.731071 & & & 16.03396 \\
\hline F-statistic & 3.491613 & & & 2.496148 \\
\hline Prob(F-statistic) & 0.013213 & & & \\
\hline \multicolumn{5}{|c|}{ Unweighted Statistics } \\
\hline R-squared & 0.374436 & \multirow{2}{*}{\multicolumn{2}{|c|}{$\begin{array}{l}\text { Mean dependent var } \\
\text { Durbin-Watson stat }\end{array}$}} & -3.773759 \\
\hline Sum squared resid & 16.40520 & & & 2.439663 \\
\hline
\end{tabular}

Sumber : Data Diolah Penulis, 2020

* Corresponding author's e-mail: dosen02424@unpam.ac.id

http://openjournal.unpam.ac.id/index.php/JABI 
Model persamaan regresi yang dihasilkan dari tabel output 8 adalah:

KONS $=-7,247993-0,377902 \mathrm{KOMIND}+0,092067 \mathrm{KEPMAN}-$ 0,474711 KEPINST $+0,267180 \mathrm{UKR}+1,428793 \mathrm{DER}$

\section{Uji Signifikansi Korelasi}

Koefisien korelasi (r) digunakan untuk mengetahui kuat atau lemahnya hubungan antara variabel independen secara keseluruhan terhadap variabel dependen. Semakin besar nilai $r$ (mendekat angka 1) maka semakin kuat hubungan antara variabel independen dan dependennya.

Koefisien korelasi ( $R$-squared) pada tabel 8 menunjukan angka 0.367863 . Angka ini menjelaskan bahwa hubungan pengaruh variabel proporsi komisaris independen, kepemilikan manajerial, kepemilikan institusional, ukuran perusahaan dan debt to equity ratio terhadap konservatisme akuntansi adalah lemah.

\section{Uji Koefisien Determinasi}

Tampilan output pada tabel 8 menunjukan besarnya adjusted $R 2$ sebesar 0.262507 , hal ini berarti hanya $26 \%$ variasi konservatisme akuntansi dapat dijelaskan oleh variasi dari lima variabel independen variabel proporsi komisaris independen, kepemilikan manajerial, kepemilikan institusional, ukuran perusahaan dan debt to equity ratio sedangkan sisanya $74 \%$ dijelaskan oleh sebabsebab lain diluar model dalam penelitin ini.

\section{Uji signifikansi parsial (uji t)}

Berdasarkan tabel output 8, nilai signifikansi sebesar $0.6882>0.05$ dengan nilai $\mathrm{t}_{\text {hitung }}$ sebesar $0.405234<\mathrm{t}_{\text {tabel }}$ sebesar 1.6532 , berdasarkan hasil di atas maka $\mathrm{H}_{1}$ ditolak dan $\mathrm{H}_{0}$ diterima, yang berarti proporsi komisaris independen tidak berpengaruh terhadap konservatisme akuntansi secara parsial. Berdasarkan tabel output 8, nilai signifikansi $0.1746>0.05$ dengan nilai $t_{\text {hitung }}$ sebesar $1,39042<t_{\text {tabel }}$ sebesar 1,6532, berdasarkan hasil di atas maka $\mathrm{H}_{1}$ ditolak dan $\mathrm{H}_{0}$ diterima, yang berarti kepemilikan manajerial tidak berpengaruh terhadap konservatisme akuntansi secara parsial. Berdasarkan tabel output 8, nilai signifikansi sebesar $0.6837>0.05$ dengan nilai thitung sebesar $0,41143<t_{\text {tabel }}$ sebesar 1,6532, berdasarkan hasil di atas maka $\mathrm{H}_{1}$ ditolak dan $\mathrm{H}_{0}$ diterima, yang berarti kepemilikan manajerial tidak berpengaruh terhadap konservatisme akuntansi secara parsial. Berdasarkan tabel 8, nilai signifikansi sebesar $0.0062<0.05$ dengan nilai thitung sebesar 2,94399 $>\mathrm{t}_{\text {tabel }}$ sebesar 1,6532, berdasarkan hasil di atas maka $\mathrm{H}_{0}$ ditolak dan $\mathrm{H}_{1}$ diterima, yang berarti ukuran perusahaan berpengaruh terhadap konservatisme akuntansi secara parsial. Berdasarkan tabel output 8 , nilai signifikansi sebesar $0.0040<0.05$ dengan nilai $t_{\text {hitung }}$ sebesar $3,12145>t_{\text {tabel }}$ sebesar 1,6532, berdasarkan hasil diatas maka $\mathrm{H}_{0}$ ditolak dan $\mathrm{H}_{1}$ diterima, yang berarti debt to equity ratio berpengaruh signifikan terhadap konservatisme akuntansi secara parsial.

* Corresponding author's e-mail: dosen02424@unpam.ac.id

http://openjournal.unpam.ac.id/index.php/JABI 
Hasil uji pengaruh simultan (Uji F)

Uji pengaruh simultan (uji F) dilakukan untuk mengetahui apakah variabel independen secara bersama-sama atau simultan mempengaruhi variabel dependen. Untuk uji signifikan regresi berganda dapat dilihat dari data dari hasil pengujian signifikan dan uji F. Hasilnya dapat dilihat pada tabel 8, bahwa diperoleh nilai F hitung sebesar 3,4191613 dengan probabilitas sebesar 0.013213. Oleh karena probabilitas jauh lebih kecil dari 0.05 , maka dapat disimpulkan bahwa koefisien regresi KOMIND,KEPMAN, KEPINST, UKR, DER tidak sama dengan nol atau dengan kata lain $\mathrm{H}_{1}$ diterima dan menolak $\mathrm{H}_{0}$. Kesimpulan hasil outputnya adalah kelima variabel independen secara bersama-sama berpengaruh signifikan terhadap konservatisme akuntansi. Dengan demikian $\mathrm{H}_{6}$ dalam penelitian ini terbukti.

\section{Pembahasan}

\section{Proporsi komisaris independen terhadap konservatisme akuntansi}

Tabel output 8 menunjukkan nilai signifikansi $0.6882>0.05$ dengan nilai $\mathrm{t}_{\text {hitung }}$ sebesar $0.405234<\mathrm{t}_{\text {tabel }}$ sebesar 1.6532. Hal ini menunjukkan bahwa proporsi komisaris independen tidak berpengaruh terhadap konservatisme akuntansi. Hal ini didasari bahwa komisaris independen merupakan orang yang berasal dari luar perusahaan, ini memungkinkan pengetahuan komisaris independen tentang keadaan perusahaan juga relatif terbatas. Sehingga menyebabkan kurang efektifnya peran komisaris independen di dalam peningkatan kinerja perusahaan, dikarenakan adanya kemungkinan bahwa dewan direksi dan komisaris tidak terlalu mempertimbangkan masukan-masukan yang diberikan oleh pihak komisaris independen. Hal ini juga menunjukkan bahwa tingkat pengawasan dan tingkat penerapan konservatisme yang dilakukan oleh pihak komisaris independen terhadap manajer tidak berjalan secara efektif. Sehingga berapapun banyaknya dewan komisaris independen yang dimiliki perusahaan, tidak mempunyai pengaruh yang besar dalam penerapan konservatisme akuntansi di perusahaan tersebut. Hasil penelitian ini sejalan dengan Veres (2013) dan Mulya (2014) yang menemukan tidak adanya pengaruh komisaris independen terhadap konservatisme akuntansi.

\section{Kepemilikan manajerial terhadap konservatisme akuntansi}

Tabel output 8 menunjukkan nilai signifikansi $0.1746>0.05$ dengan nilai $t_{\text {hitung }}$ sebesar $1,39042<\mathrm{t}_{\text {tabel }}$ sebesar 1,6532. Hal ini menunjukkan bahwa kepemilikan manajerial tidak berpengaruh terhadap konservatisme akuntansi. Pada tabel 3, nilai rata-rata kepemilikan manajerial menunjukan nilai 0,011. Nilai ini menunjukkan bahwa jumlah kepemilikan saham manajerial pada perusahaan sektor perbankan yang menjadi sampel penelitian masih sangat rendah. Rendahnya rata-rata kepemilikan saham para manajer dalam perusahaan tersebut menyebabkan keputusan mereka tidak terlalu mempengaruhi keputusan perusahaan dalam menerapkan akuntansi konservatisme. Para manajer akan menjalankan tugasnya sesuai dengan peran dan tanggungjawabnya, tanpa perlu mementingkan keuntungan untuk dirinya sendiri. Hasil penelitian ini sejalan 
dengan Veres (2013) dan Mulya (2014 yang menemukan tidak adanya pengaruh kepemilikan manajerial terhadap konservatisme akuntansi

\section{Kepemilikan institusional terhadap konservatisme akuntansi}

Tabel output 8 menunjukkan nilai signifikansi sebesar $0.6837>0.05$ dengan nilai thitung sebesar $0,41143<$ ttabel sebesar 1,6532, Hal ini menunjukkan bahwa kepemilikan institusional tidak berpengaruh terhadap konservatisme akuntansi. Pada tabel 3, nilai rata-rata kepemilikan institusional menunjukan nilai 0,792 atau sekitar $79 \%$ total saham yang dimiliki oleh pihak institusional. Hasil ini sejalan dengan konsep yang mengatakan bahwa kepemilikan institusional adalah pemilik saham yang hanya memfokuskan pada current earning (Porter,1992 dalam Veres, 2013). Adanya kepemilikan institusional akan membuat manajer merasa terikat untuk memenuhi target laba dari para investor seperti manajer terpaksa untuk melakukan tindakan yang dapat meningkatkan laba jangka pendek, misalnya dengan melakukan manipulasi laba atau tidak menerapkan prinsip konservatisme. Apabila laba yang diperoleh perusahaan rendah, maka akan ada kemungkinan pihak investor ini dapat melikuidasi sahamnya. Hal tersebut mungkin merupakan penyebab kepemilikan institusional tidak berpengaruh terhadap konservatisme akuntansi. Hasil penelitian ini juga sejalan dengan Veres (2013) dan Mulya (2014) yang menemukan tidak adanya pengaruh kepemilikan institusional terhadap konservatisme akuntansi

\section{Ukuran perusahaan terhadap konservatisme akuntansi}

Tabel output 8 menunjukkan nilai signifikansi sebesar $0.0062<0.05$ dengan nilai thitung sebesar 2,94399 > ttabel sebesar 1,6532. Yang menunjukkan bahwa ukuran perusahaan berpengaruh terhadap konservatisme akuntansi. Dengan Semakin besar ukuran perusahaan maka semakin konservatif perusahaan tersebut. Berdasarkan teori akuntansi positif, ukuran perusahaan berhubungan dengan biaya politik, semakin besar ukuran perusahaan maka semakin besar biaya politis yang akan diberikan kepada perusahaan tersebut, seperti pemerintah yang akan menetapkan pajak yang lebih besar pada perusahaan tersebut, sehingga perusahaan akan semakin berhati-hati dan berusaha untuk mengakui rugi terlebih dahulu daripada laba, dan ini membuat laporan keuangan menjadi konservatif. Penelitian ini mendukung Daljono (2013) dan Sari dan Adhariani (2009) yang menyatakan bahwa ukuran perusahaan berpengaruh positif terhadap tingkat konservatisme perusahaan..

\section{DER terhadap konservatisme akuntansi}

Berdasarkan hasil penelitian yang tertera pada tabel 8, ditemukan bahwa $D E R$ berpengaruh secara signifikan dengan arah koefisien positif terhadap konservatisme akuntansi, $0.0040<0.05$ dengan nilai $t_{\text {itung }}$ sebesar 3,12145 $>t_{\text {tabel }}$ sebesar 1,6532. Nilai positif koefisien regresi DER menunjukan hubungan yang bersamaan arah antara debt to equity ratio dan konservatisme akuntansi, ini berarti jika persentase DER semakin meningkat, maka nilai konservatisme juga akan meningkat sebesar 1,4287. Hal ini dikarenakan bahwa semakin besar nilai $D E R$, semakin besar pula kemungkinan perusahaan akan menggunakan prosedur yang

* Corresponding author's e-mail: dosen02424@unpam.ac.id

http://openjournal.unpam.ac.id/index.php/JABI 
meningkatkan laba yang dilaporkan periode sekarang atau laporan keuangan disajikan cenderung tidak konservatif (optimis) (Sari dan Adhariani, 2009). Hal ini dapat dikarenakan perusahaan dengan tingkat utang yang semakin tinggi akan menggunakan pilihan kebijakan akuntansi untuk memperbaiki rasio keuangan dan mengurangi kemungkinan pemutusan perjanjian utang. Maka yang terjadi adalah perusahaan menyajikan laporan keuangan cenderung tidak konservatif. Hasil penelitian ini sejalan dengan Yustina (2013) dan Fina, et,al. (2016) menemukan adanya pengaruh positif signifikan leverage dengan proksi DER terhadap konservatisme akuntansi.

\section{KESIMPULAN DAN SARAN}

\section{Kesimpulan}

Berdasarkan hasil analisis data dan pembahasan yang telah dikemukakan, diperoleh hasil yang menyebutkan bahwa :

1. Proporsi komisaris independen tidak berpengaruh signifikan terhadap konservatisme akuntansi.

2. Kepemilikan manajerial tidak berpengaruh signifikan terhadap konservatisme akuntansi.

3. Kepemilikan institusional tidak berpengaruh secara signifikan terhadap konservatisme akuntansi

4. Ukuran perusahaan berpengaruh secara signifikan dengan arah koefisien positif terhadap konservatisme akuntansi

5. Debt to equity ratio berpengaruh secara signifikan dengan arah koefisien positif terhadap konservatisme akuntansi.

6. Proporsi komisaris independen, kepemilikan manajerial, kepemilikan institusional, ukuran perusahaan, dan debt to equity ratio berpengaruh secara bersama-sama terhadap konservatisme akuntansi.

\section{Saran}

Bagi peneliti selanjutnya,

1. Memperluas objek penelitian seperti menggunakan sampel perusahaan dari sektor lain selain perbankan sehingga hasil penelitian lebih beragam.

2. Menambahkan karakteristik-karakteristik yang lebih detail tentang masingmasing variabel. Menambahkan variabel-variabel lain yang berhubungan dengan corporate governance yang belum diteliti dalam penelitian ini.

3. Pendekatan yang digunakan untuk mengukur konservatisme akuntansi dapat diganti dengan proksi lain selain perubahan akrual, contohnya dapat diukur dengan Earnings atau Stock Return Realtion Measures,Net Asset Measures atau Discretionary Accruals.

Bagi perusahaan dan pihak yang berkepentingan dengan perusahaan,

1. Sebaiknya manajer perusahaan mempertimbangkan apakah perusahaan menerapkan prinsip akuntansi yang konservatif atau tidak. Perusahaan yang

* Corresponding author's e-mail: dosen02424@unpam.ac.id

http://openjournal.unpam.ac.id/index.php/JABI 
konservatif cenderung lebih berhati-hati dalam mengakui laba sehingga kemungkinan manajemen menyajikan laba yang overstated lebih kecil.

2. Bagi investor, agar dapat lebih berhati-hati dalam memahami laba yang dilaporkan manajemen perusahaan dalam laporan keuangan, investor harus dapat ikut andil memberikan tingkat pengawasan yang cukup tinggi demi tercapainya tujuan perusahaan.

3. Sebaiknya pihak yang berkepentingan dengan perusahaan terutama investor dan kreditur memperhatikan angka $D E R$ perusahaan sebagai pertimbangan untuk melakukan investasi atau memberikan pinjaman.

\section{DAFTAR PUSTAKA}

Agustin, et, al (2019), “ Pengaruh porsi Kepemilikan publik, Proporsi Dewan Komisaris Independen, Dan Ukuran KAP Terhadap Pengungkapan Sukarela", Jurnal Akuntansi Berkelanjutan Indonesia, Vol. 2, No,1.

Ahmed, A. and S. Duellman. (2007). "Accounting conservatism and board of director characteristics": An empirical analysis, Journal of Accounting and Economics. .

Belkaoui, Ahmed Riohi. (2004). Accounting Theory. Salemba Empat, Jakarta..

Daljono, Willyza P.H. (2013). "Pengaruh Ukuran Perusahaan, Rasio Leverage, Intensitas Modal, dan Likuiditas Perusahaan terhadap Konservatisme Akuntansi Perusahaan" Journal of Accounting Vol.2 No.3.

Fina, et.al. (2016) "Pengaruh Risiko Litigasi, Leverage, dan Tingkat Kesulitan Keuangan Perusahaan terhadap Konservatisme Akuntansi" Prosiding Akuntansi

Gideon, Boediono S.B. (2005). "Kualitas Laba: Studi Pengaruh Mekanisme Corporate Governance dan Dampak Manajemen Laba dengan Analisis Jalur" Simposium Nasional Akuntansi VIII, Solo, September

Givoly, D. Hayn, C. (2002). "The changing time-series properties of earnings, cash flows and accruals: has financial reporting become more conservative?" Journal of Accounting and Economics 29, 287-320.

Gunarto, Kelvin dan Riswandari, Ernie (2019), “ Pengaruh Diversifikasi Operasi, Kepemilikan Manajerial, Komite Audit dan Kualitas Audit terhadap Manajemen Laba”, Jurnal Akuntansi Berkelanjutan Indonesia, Vol.2, No.3.

Haniati, Sri., dan Fitriany. (2010). "Pengaruh Konservatisme terhadap Asimetri Informasi dengan Menggunakan Beberapa Model Pengukuran Konservatisme" Simposium Nasional Akuntansi 13, Purwokerto.

Jensen, M. C. dan W. H. Meckling, (1976). "Theory of the Firm: Managerial Behavior, Agency Cost, and Ownership Structure" Journal of Financial Economics.

LaFond, Ryan and Roychowdhury, Sugata. (2007). "Managerial Ownership and Accounting Conservatism" ssrn.929693.

Millah, et al. (2020). "Analisis Pengaruh Konservatisme Akuntansi dan Struktur Modal terhadap Kinerja Keuangan Perusahaan" Jurnal Akutansi Berkelanjutan Indonesia, Vol 3, No.1

* Corresponding author's e-mail: dosen02424@unpam.ac.id

http://openjournal.unpam.ac.id/index.php/JABI 
Mulya, Anissa Amalia. (2014). "Pengaruh Good Corporate Governance, Audit Brand Name, dan Ukuran Perusahaan terhadap Konservatisme Akuntansi" Jurnal akuntansi keuangan, Vol.3 No.2

Mutia, Evi, Zuraida, dan Devi Andriani. (2011). "Pengaruh Ukuran Perusahaan, Profitabilitas dan Ukuran Dewan Komisaris terhadap Pengungkapan Corporate Social Responsibility pada Perusahaan Manufaktur yang Terdaftar di Bursa Efek Indonesia" Jurnal Telaah dan Riset Akuntansi, Vol. 4, No. 2: 187-201.

Nugroho, Deffa Agung dan Mutmainah.(2012). "Pengaruh Struktur Kepemilikan Manajerial, Debt Covenant, Tingkat Kesulitan Keuangan dan Risiko Litigasi Terhadap Konservatisme Akuntansi (Studi Empiris Pada Perusahaan Manufaktur Yang Terdaftar Di BEI Tahun 2008-2010)", Tesis Fakultas Ekonomika Dan Bisnis. Universitas Diponegoro.

Oktomegah, Calvin (2012). "Faktor-Faktor yang Mempengaruhi Konservatisme pada Perusahaan Manufaktur di BEI" Jurnal Ilmiah Mahasiswa Akuntansi, Vol.1, No.1.

Sari, Cynthia dan Desi Adhariani. (2009). "Konservatisme Perusahaan di Indonesia dan Faktor - faktor yang Mempengaruhinya" Jurnal Universitas Indonesia.

Veres, Mariska. (2013). "Hubungan Mekanisme Good Corporate Governance dan Kualitas Kantor Akuntan Publik terhadap Konservatisme Akuntansi” Jurnal ilmiah mahasiswa, Vol.2 No.1.

Wardhani, Ratna. (2008). "Tingkat Konservatisme Akuntansi Di Indonesia Dan Hubugannya Dengan Karakteristik Dewan Sebagai Salah Satu Mekanisme Good Corporate Governance" Simposium Nasional Akuntansi 11. Ikatan Akuntan Indonesia

Watts, Ross L. (2003). "Conservatism in Accounting - Part Ii: Evidence and Research Opportunities", Simon Business School Working Paper No. FR 032, http://dx.doi.org/10.2139/ssrn.438662

Yustina, Reny. (2013). "Pengaruh Konvergensi IFRS dan Mekanisme Good Corporate Governance terhadap Tingkat Konservatisme Akuntansi" Jurnal Ilmiah Mahasiswa, FEB.

Zarkasyi, H. Moh. Wahyudin. (2008). Good Corporate Governance pada Badan Usaha Manufaktur, Perbankan dan Jasa Keuangan Lainnya, Bandung : Alfabeta

Zulaikha, Dwinita Wulandini. (2012). "Pengaruh karakteristik Dewan Komisaris dan Komite Audit terhadap tingkat konservatisme Akuntansi" Journal of accounting, Vol.1 no.2.

Liputan6, "Skandal terungkap CEO Thosiba Mundur" (22 juli 2015). (http://bisnis.liputan6.com/read/2277114/skandal-terungkap-ceo-toshibamundur diakses 15 Agustus 2020). 